\title{
Hepatoprotective Effect of Caesalpinia sappan L. Ethanolic Extract on Alloxan Induced Diabetic Rats
}

\section{(Efek Hepatoprotektif Ekstrak Etanol Caesalpinia sappan L pada Tikus Diabetes Terinduksi Aloksan)}

\author{
Diana Holidah $^{1}$, Ika Puspita Dewi*1, Iskandar P. A. Siregar ${ }^{1}$, Dwi Aftianingsih ${ }^{1}$ \\ ${ }^{I}$ Preclinical Pharmacology Research Group, Faculty of Pharmacy Universitas Jember Indonesia \\ *E-mail: ikapdewi@unej.ac.id
}

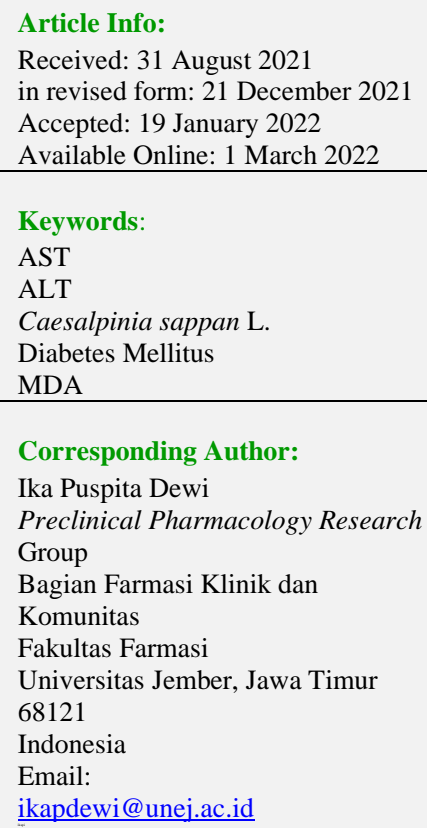

\begin{abstract}
Background: The complications of Diabetes Mellitus (DM) may lead to other health problems such as heart attack, stroke, kidney failure, leg amputation, vision loss, nerve and liver damage. Increasing free radicals in the hyperglycemic condition in DM can induce inflammation and necrosis that lead to liver damage. This damage causes elevated hepatic enzymes such as aspartate aminotransferase (AST) and alanine aminotransferase (ALT). Malondialdehyde (MDA) is a biomarker that is often used to evaluate oxidative stress including in vivo experimental models of diabetes. Caesalpinia sappan L. is one of the well-known herbs which has a strong antioxidant effect and has various pharmacology activities, including antidiabetic and hepatoprotective. Objectives: This study is aimed to investigate the effect of Caesalpinia sappan L. ethanolic extract on liver function and antioxidant status in diabetic rats. Material and Methods: Twenty-four diabetic male rats were divided into six groups consisting of the normal control group, negative control, positive control, and Caesalpinia sappan L. extract treatment group at a dose of 50, 100, and 400 $\mathrm{mg} / \mathrm{kg} \mathrm{BW}$. The diabetic status was induced by alloxan. The animals were given treatment for 14 days, and on the $15^{\text {th }}$ day, their blood and liver were collected to measure the level of AST, ALT, plasma MDA, and liver MDA. Results: The extracts of Caesalpinia sappan L. can decrease the levels of AST and ALP and show a low number of MDA levels both in plasma and liver on diabetic rats induced by alloxan. The dose of $100 \mathrm{mg} / \mathrm{kg}$ BW has the best result for lowering AST and ALT levels; meanwhile, the dose of $400 \mathrm{mg} / \mathrm{kg}$ BW shows the least value of MDA among all the doses. Conclusions: The Caesalpinia sappan L. ethanolic extract has potential activity as the hepatoprotective and antioxidant in diabetic status.
\end{abstract}




\begin{abstract}
ABSTRAK
Latar Belakang: Komplikasi Diabetes Melitus (DM) dapat menyebabkan berbagai masalah kesehatan seperti serangan jantung, stroke, gagal ginjal, amputasi kaki, kehilangan penglihatan, kerusakan saraf dan liver. Kondisi hiperglikemia pada DM memicu peningkatan kadar radikal bebas yang menyebabkan inflamasi dan nekrosis pada hati. Kerusakan ini akan meningkatkan nilai enzim hati seperti aspartate aminotransferase (AST) dan alanine aminotransferase (ALT). Malondialdehyde (MDA) merupakan biomarker yang biasa digunakan untuk mengetahui tingkat stres oksidatif pada berbagai model in vivo termasuk diabetes. Caesalpinia sappan L. atau secang merupakan salah satu herba yang dikenal memiliki aktivitas sebagai antioksidan selain sebagai antidiabetes dan hepatoprotektor. Tujuan: Penelitian ini dilakukan untuk mengetahui efek ekstrak etanol Caesalpinia sappan L. pada fungsi liver dan status antioksidan tikus diabetes. Bahan dan Metode: Dua puluh empat tikus jantan galur Wistar dibagi menjadi enam grup yaitu grup kontrol normal, kontrol negatif, kontrol positif, dan pemberian ekstrak Caesalpinia sappan $\mathrm{L}$. dengan dosis 50, 100, dan $400 \mathrm{mg} / \mathrm{kgBB}$. Induksi diabetes dilakukan menggunakan aloksan. Perlakuan dilakukan selama 14 hari dan pada hari ke-15, darah dan liver hewan uji diambil untuk mengukur nilai AST, ALT, dan MDA plasma dan liver. Hasil: Ekstrak Caesalpinia sappan L. dapat menurunkan nilai AST dan ALT serta menunjukkan nilai MDA yang rendah baik pada plasma maupun liver pada tikus terinduksi diabetes. Dosis yang paling efektif menurunkan AST dan ALT adalah $100 \mathrm{mg} / \mathrm{kgBB}$, sedangkan dosis yang memberikan nilai MDA paling rendah adalah $400 \mathrm{mg} / \mathrm{kgBB}$. Kesimpulan: Ekstrak etanol Caesalpinia sappan L. memiliki potensi sebagai hepatoprotektor dan antioksidan pada tikus dengan diabetes.
\end{abstract}

Kata kunci: AST, ALT, Caesalpinia sappan L.; Diabetes Melitus (DM); MDA

\title{
INTRODUCTION
}

Diabetes Mellitus (DM) is one of the non-communicable diseases which shows of increasing prevalence trend every year in Indonesia (Kementerian Kesehatan RI, 2020). The complications of this disease may lead to other health problems such as heart attack, stroke, kidney failure, leg amputation, vision loss, and nerve damage (World Health Organization, 2016). DM can also cause liver damage. Elevated hepatic enzymes such as aspartate aminotransferase (AST) and alanine aminotransferase (ALT), acute liver disease, non-alcoholic fatty liver disease (NAFLD), abnormal glycogen deposition, fibrosis, cirrhosis, and hepatocellular carcinomas (HCCs) are liver abnormalities associated with DM. Liver accumulated with fat may exacerbate diabetes status by leading to insulin resistance and severe metabolic dysfunction. This condition can damage hepatocytes and increase morbidity and mortality of patients with DM (Mohamed et al., 2016).

A high number of free radicals occurs in uncontrolled hyperglycemic conditions. This condition is caused by reactive oxygen species (ROS) from glucose autoxidation and protein glycosylation and leads to the degradation and loss of function of macromolecules such as carbohydrates, proteins, lipids, and Deoxyribonucleic acid (DNA) (Fatani et al., 2016). Increasing levels of ROS can induce inflammation and necrosis that lead to liver damage (Mohamed et al., 2016).

Liver damage in diabetes can occurs due to the accumulation of lipids in hepatocyte cells that trigger the formation of ROS (Szendroedi et al., 2012). ROS can attack lipids containing carbon-carbon double bonds, especially polyunsaturated fatty acids (PUFA), and produce the main product in the form of lipid 
hydroperoxides and secondary products in the form of aldehydes such as malondialdehyde (MDA), propenal, hexanal, and 4-hydroxynonenal. Malondialdehyde (MDA) is a biomarker that is often used to evaluate oxidative stress including in vivo experimental models of diabetes (Fatani et al., 2016). MDA is a product of lipid peroxidation and provides an indication of the overall level of lipid peroxidation (Ghazizadeh et al., 2018). The relationship between MDA levels and the degree of liver damage is that the more severe the liver damage, the higher the MDA levels (Safithri et al., 2018). Giving antioxidants from outside the body may reduce the MDA levels in patients with DM type 2 (Mahreen et al., 2010).

Caesalpinia sappan L., or sappan-wood or kayu secang in Indonesia, is one of the well-known herb which has a strong antioxidant effect (Badami et al., 2003; Wetwitayaklung et al., 2005). This plant is commonly used for natural colorant because of its red color (Ngamwonglumlert et al, 2020; Nirmal et al, 2015). C. sappan L. has various pharmacology activities, including antimicrobial, antidiabetic, cytotoxic, hepatoprotective, and antitumor abilities (Badami et al., 2004; Holidah et al, 2021). Several types of phytochemicals of this plant include phenolic compounds such as xanthones, coumarins, chalcones, flavonoids, homoisoflavonoids such as brazilin. Brazilin is the main homoisoflavonoid compound that can be found in C. sappan L. and is often used as a natural red dye. Brazilin has activity as an antidiabetic and antioxidant that can protect the body from chemical radicals (Nilesh et al, 2015; Nilesh \& Panichayupakaranant, 2015). Brazilin also has activity as a hepatoprotector (Chandrashekhar et al., 2010). The effect of $C$. sappan L. in the liver function of the diabetic case has not been known. Based on that, this study is conducted to investigate the effect of Caesalpinia sappan L ethanolic extract on liver function and antioxidant status in diabetic rats.

\section{MATERIAL AND METHODS}

\section{Materials}

The herb of Caesalpinia sappan L. was from Sumenep, Madura that have been identified by Laboratory of Plant at Jember State Polytechnic (No 63/PL17.3.1.02/LL/2018). The chemicals used in this research were alloxan (Tokyo Chemicals Industry), glibenclamide (PT Paphros, Indonesia), Carboxymethylcellulose sodium (CMA Na), $\mathrm{NaOH}$, trichloroacetic (TCA), thiobarbituric acid (TBA), 1,1,3,3-tetraetoxy propane (TEP) were from Sigma Aldrich, ethanol, $\mathrm{NaCl}$ and aqua dest were obtained from local firms. The AST and ALT reagents for blood biochemical analysis from Analyticon Germany.

\section{Methods}

The Caesalpinia sappan L ethanolic extract (CSEE) was made by maceration. Caesalpinia sappan L. powder (250 grams) was macerated with ethanol $96 \%$ for two days. The filtrate was filtered using a Buchner funnel and then concentrated with a rotary evaporator at $50^{\circ} \mathrm{C}$ until a thick extract was obtained. The remaining solvent was evaporated in an oven at $40^{\circ} \mathrm{C}$ until the weight of CSEE was constant. 
The method of this study was done according to Holidah, Christianty, \& Ilma (2016). The animals used in this study were male Wistar rats (200-300 grams and 2-3 months old) obtained from the Laboratory of Pharmacology, Faculty of Pharmacy University of Jember. Twenty-four rats were randomly divided into six groups ( $\mathrm{n}=4 /$ group) consisting of normal control, negative control, positive control, and Caesalpinia sappan L ethanolic extract (CSEE) at the dose of 50,100, and $400 \mathrm{mg} / \mathrm{kg} \mathrm{BW}$. The research protocol was approved by the Health Research Ethics Commission, Faculty of Dentistry, University of Jember (No 455/UN25.8/KEPK/DL/2019).

The normal control group was given CMC Na 1\% daily for 14 days. All groups, except the normal group, were given alloxan $135 \mathrm{mg} / \mathrm{kg} \mathrm{BW}$ intraperitoneally to induce diabetes. On the $3^{\text {rd }}$ day after induction with alloxan, the blood glucose levels of the animals were checked. If the blood glucose level is above $200 \mathrm{mg} / \mathrm{dL}$, the rats can be used for the next stage of research. The blood sample was taken from the animal and considered as before-treatment data. The negative control group was administered with $\mathrm{CMC} \mathrm{Na} 1 \%$ orally for 14 days; the positive control group was given with glibenclamide $0.9 \mathrm{mg} / \mathrm{kg}$ BW for 14 days; and the treatment groups were given CSEE with doses of 50, 100 and $400 \mathrm{mg} / \mathrm{kg} \mathrm{BW}$ for 14 days. After 14 days of treatment (on the $15^{\text {th }}$ day), the animals were sacrificed. The blood of the rats was taken to measure the level of AST, ALT, and MDA level; meanwhile, the liver was taken to evaluate the MDA liver level to collect the after-treatment data. Measurement of the MDA levels in rat liver tissue and plasma was carried out using the Thiobarbituric Acid Reactive Substances (TBARS) method with a UV-Vis spectrophotometer at a wavelength of $532 \mathrm{~nm}$. The AST and ALT measurement using the manual from reagents manufacturer's instruction using a photometer (Biolyzer 100). The percentage decrease of the AST and ALT data were calculated using the equation formula as below:

$$
\% \text { decrease }=\frac{\text { before treatment }- \text { after treatment }}{\text { before treatment }} \times 100 \%
$$

Data analysis was done using one-way ANOVA with SPSS software. The analysis was continued with Least Significantly Different (LSD) to test the analysis variance between groups with a $95 \%$ confidence level.

\section{RESULTS AND DISCUSSION}

The levels of AST and ALT in the blood of rats before and after treatment are shown in Table 1. After 14 days of treatment, the levels of AST and ALT of the positive control group and the treatment group of Caesalpinia sappan L ethanolic extract (CSEE) decrease. Meanwhile, the negative group shows an elevated level both in AST and ALT. Goyal et al. (2014) showed that in diabetics without fatty liver, the levels of AST and ALT increased, and there was a significant increase in diabetics with fatty liver. 
Table 1. AST and ALT Level Before and After Treatment

\begin{tabular}{ccccc}
\hline \multirow{2}{*}{ Group } & \multicolumn{2}{c}{ AST Level (mean \pm SD) $(\mathrm{U} / \mathrm{L})$} & \multicolumn{2}{c}{ ALT Level (mean \pm SD) (U/L) } \\
\cline { 2 - 5 } & Before treatment & After treatment & Before treatment & After treatment \\
\hline Normal & $62.59 \pm 4.90$ & $86.89 \pm 3.34$ & $20.49 \pm 2.75$ & $37.09 \pm 5.62$ \\
Negative & $117.93 \pm 17.31$ & $210.74 \pm 30.25$ & $85.22 \pm 30.23$ & $167.72 \pm 61.54$ \\
Positive & $143.19 \pm 6.05$ & $74.70 \pm 6.70$ & $86.93 \pm 24.90$ & $28.38 \pm 13.85$ \\
CSEE dose $50 \mathrm{mg} / \mathrm{kg} \mathrm{BW}$ & $153.92 \pm 46.16$ & $97.85 \pm 28.61$ & $88.19 \pm 33.71$ & $57.47 \pm 21.61$ \\
CSEE dose $100 \mathrm{mg} / \mathrm{kg} \mathrm{BW}$ & $179.50 \pm 30.27$ & $95.42 \pm 27.42$ & $117.70 \pm 35.54$ & $47.02 \pm 21.72$ \\
CSEE dose $400 \mathrm{mg} / \mathrm{kg} \mathrm{BW}$ & $241.96 \pm 122.46$ & $86.89 \pm 3.34$ & $20.49 \pm 2.75$ & $37.09 \pm 5.62$ \\
\hline
\end{tabular}

*) Data are shown in mean \pm SD with $n=4$.

The levels of AST and ALT before treatment data in all groups induced with alloxan increased compared to the normal group. This shows that the induction of alloxan at a dose of $135 \mathrm{mg} / \mathrm{kg} \mathrm{BW}$ can cause liver damage due to complications of diabetes which are characterized by increased levels of AST and ALT in the blood of rats to above the normal range. Normal levels of AST in rats are 45.7-80.8 U/L, and normal levels of ALT are 1.5-30.2 U/L (Gad and Group, 2006).

The data from the measurement of the levels of AST and ALT were then processed to obtain the percentage of decrease data. The percentage of decrease data shows the effect of the treatment given. The decrease in AST and ALT levels in the blood of rats after treatment is shown in Table 2. The data shows the administration of glibenclamide as a positive control, and the administration of CSEE can reduce the levels of AST and ALT. Meanwhile, in the negative control group, the levels of AST and ALT have increased, as indicated by a negative sign in the calculation of the percentage decrease. From the statistic test with LSD can be concluded that the administration of CSEE at a dose of $100 \mathrm{mg} / \mathrm{kg} \mathrm{BW}$ can reduce AST and ALT levels in diabetic rats as well as the positive control group.

Table 2. ALT and AST Percentage of Decrease Before and After Treatment

\begin{tabular}{ccc}
\hline \multirow{2}{*}{ Group } & \multicolumn{2}{c}{ Decrease Percentage (\%) } \\
\cline { 2 - 3 } & AST (mean \pm SD) & ALT (mean \pm SD) \\
\hline Negative & $-78.92 \pm 7.90^{\mathrm{a}}$ & $-96.26 \pm 6.92^{\mathrm{a}}$ \\
Positive & $47.90 \pm 2.76^{\mathrm{b}}$ & $68.60 \pm 7.19^{\mathrm{b}}$ \\
CSEE dose $50 \mathrm{mg} / \mathrm{kg} \mathrm{BW}$ & $36.33 \pm 4.78^{\mathrm{c}}$ & $34.11 \pm 5.29^{\mathrm{c}}$ \\
CSEE dose $100 \mathrm{mg} / \mathrm{kg} \mathrm{BW}$ & $47.62 \pm 7.33^{\mathrm{b}}$ & $61.23 \pm 7.06^{\mathrm{b}}$ \\
CSEE dose 400 $\mathrm{mg} / \mathrm{kg} \mathrm{BW}$ & $32.03 \pm 5.10^{\mathrm{c}}$ & $37.50 \pm 6.56^{\mathrm{c}}$ \\
\hline
\end{tabular}

*) Data are shown in mean \pm SD with $n=4$.The same superscript letters indicate that there is no significant difference between the average decrease in SGOT and SGPT levels with the treatment group using the LSD test $(\mathrm{p}<0,05)$.

The activity of Caesalpinia sappan L. ethanolic extract to reduce AST and ALT blood levels in alloxaninduced diabetic rats may cause by its brazilin compounds. Brazilin is the major active ingredient and commonly found in C. sappan (Ngamwonglumlert et al., 2020). Brazilin is a phenolic compound that easily oxidized to brazilein which is a red-color pigments used as the main characteristic of C. sappan (Ngamwonglumlert et al., 2020; Nirmal et al., 2015; Nirmal \& Panichayupakaranant, 2015). This 
phenolic has hepatoprotective activity on carbon tetrachloride-induced hepatotoxicity (Srillakshmi et al., 2010). Brazilin can prevent the loss of glutathione in the liver due to $\mathrm{BrCCl}_{3}$ induction (Moon et al., 1992). The liver produces glutathione to protect the liver from oxidative stress. The damage of the liver can reduce glutathione production (Chen et al., 2013). By preventing the decline in glutathione levels, Brazilin can prevent liver damage from oxidative stress.

One of the most commonly used biomarkers to evaluate oxidative stress is malondialdehyde (MDA) (Fatani et al., 2016). MDA is formed because of lipid peroxidation and provides an indication of the overall level of lipid peroxidation (Ghazizadeh et al., 2018). The relationship between MDA levels and the degree of liver damage is that the more severe the liver damage, the higher the MDA levels (Safithri et al., 2018). The MDA level after 14 days of treatment of each group as described in Table 3 for plasma and liver MDA.

Table 3. MDA Level

\begin{tabular}{ccc}
\hline \multirow{2}{*}{ Group } & \multicolumn{2}{c}{ MDA Level $(\mu \mathrm{M}) \pm$ SD } \\
\cline { 2 - 3 } & Plasma MDA & Liver MDA \\
\hline Normal & $2.331 \pm 0.845^{\mathrm{a}}$ & $5.133 \pm 0.725^{\mathrm{e}}$ \\
Negative & $13.175 \pm 1.128^{\mathrm{b}}$ & $13.355 \pm 1.840^{\mathrm{f}}$ \\
Positive & $4.470 \pm 0.584^{\mathrm{c}}$ & $5.675 \pm 1.905^{\mathrm{e}}$ \\
CSEE dose $50 \mathrm{mg} / \mathrm{kg} \mathrm{BW}$ & $8.837 \pm 1.141^{\mathrm{d}}$ & $10.524 \pm 2.058^{\mathrm{g}}$ \\
CSEE dose $100 \mathrm{mg} / \mathrm{kg} \mathrm{BW}$ & $5.343 \pm 1.191^{\mathrm{c}}$ & $8.416 \pm 2.622^{\mathrm{e}}$ \\
CSEE dose $400 \mathrm{mg} / \mathrm{kg} \mathrm{BW}$ & $3.657 \pm 1.657^{\mathrm{c}}$ & $7.964 \pm 0.571^{\mathrm{e}}$ \\
\hline
\end{tabular}

*)Data are shown in mean \pm SD with $n=4$. The same superscript letters indicate that there is no significant difference between the average MDA levels with the treatment group using the LSD test $(p<0,05)$.

The MDA levels showed the negative group has the highest MDA level, both plasma and liver, compared to the other group; meanwhile, the positive and CSEE treatment show MDA level both in plasma and liver is lower than the negative group. The results of the LSD test show that the negative control group is significantly different from the normal control group, which indicates that alloxan can increase the MDA levels of rat liver tissue. The positive control group and CSEE group at a dose of 400 $\mathrm{mg} / \mathrm{kg}$ BW significantly have lower liver tissue MDA levels than the negative control group. This indicates that glibenclamide and ethanol extract of Caesalpinia sappan L. have activity as an antioxidant in liver tissue.

Caesalpinia sappan L. ethanolic extract can reduce MDA levels in the plasma and liver tissue of diabetic induced-alloxan, presumably, because it contains brazilin compounds that can work as antioxidants by increasing endogenous antioxidants. Badami et al. (2003) showed that the administration of methanol extract of Caesalpinia sappan L. water at doses of 50 and $100 \mathrm{mg} / \mathrm{kg} \mathrm{BW}$ for four days could increase levels of superoxide dismutase (SOD) and catalase and significantly reduce levels of thiobarbituric acid reactive substances (TBARS) in the liver and kidneys compared with $\mathrm{CCl}_{4}$-induced control. In vitro 
assay showed Brazilin has antioxidant activity with an $\mathrm{EC}_{50}$ value of $52.1 \mathrm{mg} / \mathrm{mL}$ (Nirmal and Panichayupakaranant, 2015).

Brazilin has a heterocyclic oxygen phenolic group that acts as a free radical scavenger and metal chelator. The activity of phenol groups in reducing free radicals is to become a hydrogen or electron donor agent that will react with peroxide precursors, thereby preventing the formation of peroxides or free radicals (Badami et al., 2003; Nirmal et al., 2015; Nilesh and Panichayupakaranant, 2015). The inhibiting intracellular free radical formation is a therapeutic strategy to prevent oxidative stress and vascular complications in diabetes mellitus (Bajaj and Khan, 2014). Antioxidant activity appears to be an excellent approach to prevent and treat liver disease because the initiation and progression of hepatic damage, which may be caused by oxidative stress (Li et al., 2015)

\section{CONCLUSION}

Caesalpinia sappan L. ethanolic extract has a potential activity to treat a liver complication in diabetic by reducing AST and ALT level, it possibly caused by its phytochemical activity that act as antioxidants.

\section{ACKNOWLEDGEMENT}

The authors would like to thank Indriasih and Herdinik for their assistance in laboratory work.

\section{CONFLICT OF INTEREST}

The authors have declared that there are no conflicts of interest.

\section{REFERENCES}

Badami, S., Moorkoth, S., Rai, S. R., Kannan, E., \& Bhojraj, S. (2003). Antioxidant activity of Caesalpinia sappan heartwood. Biological and Pharmaceutical Bulletin, 26(11), 1534-1537. https://doi.org/10.1248/bpb.26.1534

Badami, S., Moorkoth, S., \& Suresh, B. (2004). Caesalpinia sappan - A medicinal and dye yielding plant. Natural Product Radiance, 3(2), 75-82.

Bajaj, S., \& Khan, A. (2014). Mini Review Antioxidants and diabetes. Indian Journal of Endocrinology and Metabolism, 16(Suppl 2), S267-71. https://doi.org/10.4103/2230-8210.104057

Fatani, S. H., Babakr, A. T., NourEldin, E. E. M., \& Almarzouki, A. A. (2016). Lipid peroxidation is associated with poor control of type-2 diabetes mellitus. Diabetes and Metabolic Syndrome: Clinical Research and Reviews, 10(2), S64-S67. https://doi.org/10.1016/j.dsx.2016.01.028

Gad, S. C., \& Group, F. (2006). Animal Models in Toxicology $3^{\text {rd }}$ Ed. Florida: CRC press

Ghazizadeh, aniar, Khaloo, P., Alemi, H., Rabizadeh, S., Mirmiranpour, H., Esteghamati, A., \& 
Nakhjavani, M. (2018). Definition of an oxidative stress status by combined assessment of Malondialdehyde and Oxidized-LDL: A study in patients with type2 diabetes and control. Meta Gene, 19, 91-97. https://doi.org/10.1016/j.mgene.2018.10.005

Goyal, V., Chugh, K., \& Agrawal, Y. (2014). Association of serum glutamic pyruvic transaminase and non-alcoholic fatty liver disease in controlled and uncontrolled diabetes. Journal of Health Specialties, 2(4), 169. https://doi.org/10.4103/1658-600x.142788

Holidah, D., Christianty, F. M., \& Ilma, W. Z. (2016). Green Tea Extract Effect on Blood Glucose Level and Liver Histopathology in Diabetic Mice. Proceedings of the International Conference of Medicine and Health Sciences (ICMHS) (pp.35-38). Jember: Faculty of Pharmacy Universitas Jember.

Holidah, D., Dewi, I. P., Christianty, F. M., \& Muhammadiy, N. S. (2021). Antidiabetic and Antidyslipidemic activity of Secang (Caesalpinia sappan L.) Wood extract on Diabetic Rat, Research J. Pharm. and Tech, 14(5), 2801-2806. https://doi.org/10.52711/0974360X.2021.00494

Kementerian Kesehatan RI. (2020). Data dan Informasi Profil Kesehatan Indonesia 2019. Jakarta: Kementerian Kesehatan RI.

Li, S., Tan, H. Y., Wang, N., Zhang, Z. J., Lao, L., Wong, C. W., \& Feng, Y. (2015). The role of oxidative stress and antioxidants in liver diseases. International Journal of Molecular Sciences, 16(11), 26087-26124. https://doi.org/10.3390/ijms161125942

Mahreen, R., Mohsin, M., Nasreen, Z., Siraj, M., \& Ishaq, M. (2010). Significantly increased levels of serum malonaldehyde in type 2 diabetics with myocardial infarction. International Journal of Diabetes in Developing Countries, 30(1), 49-51. https://doi.org/10.4103/0973-3930.60006

Mohamed, J., Nazratun Nafizah, A. H., Zariyantey, A. H., \& Budin, S. B. (2016). Mechanisms of diabetes-induced liver damage: The role of oxidative stress and inflammation. Sultan Qaboos University Medical Journal, 16(2), e132-e141. https://doi.org/10.18295/squmj.2016.16.02.002

Ngamwonglumlert, L., Devahastin, S., \& Chiewchan, N. (2020). Color and molecular structure alterations of brazilein extracted from Caesalpinia sappan L . under different $\mathrm{pH}$ and heating conditions. Nature Research Scientific Reports, 10(12386), 1-10. https://doi.org/10.1038/s41598020-69189-3

Nirmal, N.P., Rajput, M. S., Prasad, R. G. S. V., \& Ahmad, M. (2015). Brazilin from Caesalpinia sappan 
heartwood and its pharmacological activities: A review. Asian Pacific Journal of Tropical Medicine, 8(6), 421-430. https://doi.org/10.1016/j.apjtm.2015.05.014

Nirmal, Nilesh Prakash, \& Panichayupakaranant, P. (2015). Antioxidant, antibacterial, and antiinflammatory activities of standardized brazilin-rich Caesalpinia sappan extract. Pharmaceutical Biology, 53(9), 1339-1343. https://doi.org/10.3109/13880209.2014.982295

Safithri, F., Fauziyah, A. N., \& Hermayanti, D. (2018). Penurunan Stres Oksidatif Setelah Pemberian Ekstrak Biji Jintan Hitam (Nigella sativa L.) pada Tikus Model Fibrosis Hati. Saintika Medika, 14(2), 81-86. https://doi.org/10.22219/sm.vol14.smumm2.7265

Srillakshmi, V. S., Vijayan, P., Raj, P. V., Dhanaraj, S. A., \& Chandrashekhar, H. R. (2010). Hepatoprotective properties of Caesalpinia sappan Linn. heartwood on carbon tetrachloride induced toxicity. Indian Journal of Experimental Biology, 48(9), 905-910.

Wetwitayaklung, P., Phaechamud, T., \& Keokitichai, S. (2005). The antioxidant activity of Caesalpinia sappan L. heartwood in various ages. Naresuan University Journal, 13(2), 43-52.

World Health Organization. (2016). Global Report on Diabetes (Vol. 978). Retrieved from https://apps.who.int/iris/rest/bitstreams/909883/retrieve [Accessed August 12, 2021] 